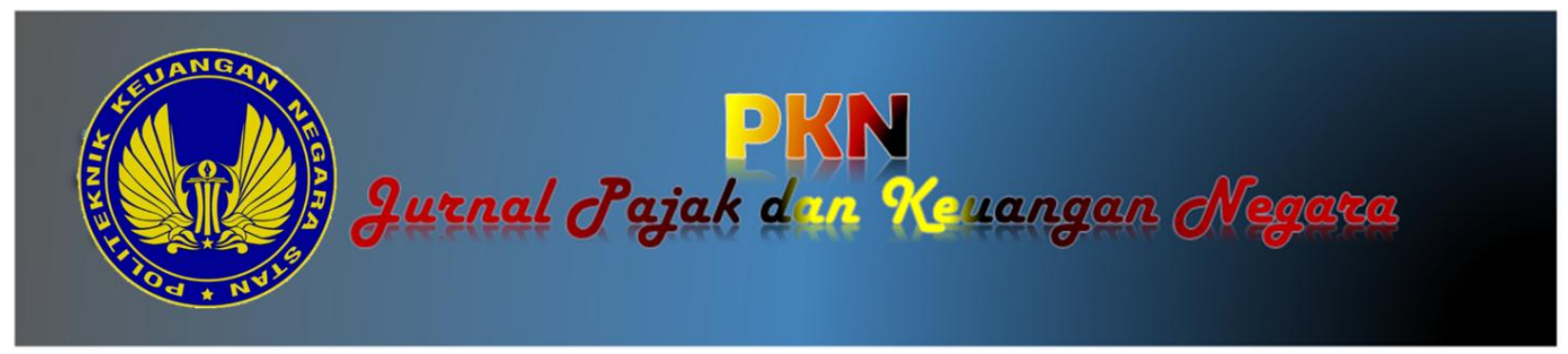

\title{
MELIHAT PERLUNYA PEMERINTAH MELAKUKAN PROGRAM REVALUASI ASET BARANG MILIK NEGARA
}

\author{
Agung Yuniarto \\ Politeknik Keuangan Negara STAN
}

Alamat Korespondensi : agung.yuniarto@pknstan.ac.id/agungyuniarto01@gmail.com

\author{
INFORMASI ARTIKEL \\ Diterima pertama \\ (3 Februari 2020) \\ Dinyatakan diterima \\ (20 Maret 2020)
}

KATA KUNCI :

Revaluasi BMN, Penilaian, Aset Tetap

KLASIFIKASI JEL :

(H82, O38)

\begin{abstract}
The Revaluation of State Assets (BMN) asset program is a revaluation of assets that belong to the state, the purpose is to increase the validity of the value of $B M N$ in the central government balance sheet, to become the underlying assets for the issuance of State Sharia Securities (SBSN), as well as building a BMN database better. The object of revaluation is fixed assets in the form of land, buildings and buildings, roads, irrigation and networks. This study explains and analyzes the problems of implementing the BMN Asset Revaluation in Indonesia. The results of this study are the government's initial efforts to improve the administration and fair value of BMN in the form of fixed assets, then presented in the central government's financial balance sheet to improve the quality of the central government's financial statements (LKPP). But this decision to revaluate is contrary to the Financial Accounting Standards and Government Accounting Standards (SAK / SAP), which adhere to asset valuations based on acquisition costs or exchange rates. However, it was concluded that the Government Accounting Standards Committee (KSAP) letter. support reporting the results of the 2017 fixed assets revaluation into LKPP, and revaluation by the government is indeed needed.
\end{abstract}

\section{ABSTRAK}

Program Revaluasi aset Barang Milik Negara (BMN) adalah penilaian kembali aset-aset yang menjadi milik negara, tujuannya adalah meningkatkan validitas nilai BMN pada dalam laporan keuangan pemerintah pusat, sebagai underlying aset dalam penerbitan Surat Berharga Syariah Negara (SBSN), sekaligus pembentukan data base BMN yang lebih baik. Objek yang dilakukan revaluasi adalah berupa aset tetap Tanah, Bangunan, Jaringan, Jalan, dan Irigasi. Studi ini menganalisa serta menjelaskan permasalahan pelaksanaan Revaluasi Aset BMN di Indonesia. Dari hasil studi ini menjadi kerja keras pemerintah untuk memperbaiki nilai wajar dan penatausahaan atas BMN aset tetap, yang disajikan dalam laporan keuangan pemerintah pusat dalam meningkatkan 
kualitas laporan keuangan pemerintah pusat (LKPP). Tetapi keputusan melakukan revaluasi ini bertentangan dengan Standar Akuntan Keuangan dan Standar Akuntansi Pemerintah (SAK/SAP), dimana menganut penilaian aset berdasarkan harga perolehan atau harga pertukaran. Akan tetapi telah disimpulkan bahwa surat Komite Standar Akuntansi Pemerintah (KSAP). mendukung pelaporan hasil revaluasi aset tetap 2017 kedalam LKPP, dan revaluasi yang dilakukan pemerintah memang diperlukan.

\section{PENDAHULUAN}

Latar belakang pemerintah melakukan revaluasi Barang Milik Negara (BMN) adalah merupakan salah satu butir Yang menjadi kesepakatan antara Menteri Keuangan dengan Komisi XI DPR RI dalam rapat kerjanya tanggal 23 Mei 2016. Pada prinsipnya Komisi XI DPR RI meminta agar Menteri Keuangan melakukan penilaian kembali terhadap aset Barang Milik Negara yang akan digunakan kembali untuk penerbitan underlying asset Surat Berharga Syariah Negara (SBSN). Manfaat lainnya untuk memperoleh nilai aset pada neraca yang updated sesuai nilai wajar terkini. Sebagaimana diketahui penilaian BMN terakhir dilaksanakan tahun 2007-2010, untuk BMN yang diperoleh sebelum tahun 2005.

Penilaian Kembali/Revaluasi Aset BMN/Daerah tertuang dalam Peraturan Presiden Nomor 75 Tahun 2017, cakupan aset yang dilakukan penilaian kembali pada tahun 2017-2018 adalah berupa berupa tanah, bangunan, serta Jaringan, jalan, dan irigasi (jalan dan jembatan, dan bangunan air/JJBA) termasuk juga aset yang sedang dalam pemanfaatan kementerian/lembaga dengan perolehan sampai dengan 31 Desember 2015.

Nilai BMN saat ini setelah dilakukan revaluasi mengalami kenaikan sebesar Rp4.190,31 triliun atau 272,42 persen dari nilai buku hasil inventarisasi sebesar Rp1.538,18 triliun. Sementara aset yang mengalami kenaikan tertinggi adalah berupa tanah, dengan kenaikan nilai tertinggi yaitu sebesar Rp3,6 triliun atau meningkat 323,22 persen dari nilai buku. Sementara, BMN lainnya seperti gedung dan bangunan naik 71,31 persen menjadi Rp275,9 triliun. Sedangkan, nilai aset jalan, jembatan, bangunan air bertambah 169,10 persen menjadi Rp 656 triliun.

Manfaat yang didapat negara dari penilaian kembali BMN yaitu mendapatkan nilai aset yang up to date dalam laporan keuangan sesuai dengan nilai wajarnya. Selain itu, quality spending yaitu terciptanya cost saving dari efisiensi Belanja Pemeliharaan karena hasil inventarisasi menghasilkan data kondisi BMN yang updated. Kemudian, pengambilan keputusan dalam pengelolaan BMN dapat lebih baik dan mendukung fungsi aset sebagai revenue center. Penilaian kembali BMN juga bermanfaat untuk mendukung sumber daya pembiayaan APBN berupa penyediaan BMN sebagai underlying asset penerbitan SBSN dan efisiensi belanja modal dengan alternatif pemenuhan kebutuhan gedung dari BMN Idle.

\section{KERANGKA TEORI}

Revaluasi aset adalah is the process of determining the fair market or present value of asset, using book value, absolute valuation models like discounted cash flow analysis, option pricing models or comparable, menurut e-economic Investopedia (2019). Di sisi lain revaluasi asset adalah melakukan penilaian kembali terhadap aset yang dimiliki Kementerian/Lembaga sehingga mencerminkan nilai aset sekarang (Martani, 2011). Sedangkan menurut Suparno (2012) revaluasi aset adalah merupakan penilaian kembali aset tetap yang dalam akuntansi pada umumnya tidak diperkenankan, karena menurutnya penilaian aset yang paling obyektif adalah berdasarkan harga perolehan atau harga pertukaran, alasannya lebih obyektif, mempunyai kredibilitas, dan dipertanggungjawabkan.

Revaluasi aset dilakukan juga untuk tujuan pendanaan dengan hutang. Menurut Nichols and Buerger (2002) bahwa pemilik bank di Jerman cenderung memberikan pinjaman yang lebih besar kepada perusahaan yang menilai asetnya dengan nilai wajar (fair value). Ada sebuah penelitian yang dilakukan oleholeh Whittred and Chan (1992) di Ausi dan penelitian oleh Lin and Peasnell (2000) di Inggris, berhasil membuktikan bahwa keputusan melakukan revaluasi aset adalah untuk mengurangi asymmetry information, political cost dan contracting cost.

Dalam Pernyataan Standar Akuntansi Pemerintahan (PSAP) 07 tentang Aset Tetap Paragraf 59, yang merupakan isi Peraturan Pemerintah Nomor 71 Tahun 2010 tentang Standar Akuntansi Pemerintahan, menyatakan bahwa "revaluasi aset tetap pada umumnya tidak diperbolehkan karena Standar Akuntansi Pemerintahan menganut penilaian aset berdasarkan harga perolehan atau harga pertukaran." Selanjutnya sesuai PP Nomor 27 Tahun 2014 tentang Pengelolaan BMN/D, Pasal 52 ayat (1) PP Nomor 27 Tahun 2014 bahwa dalam kondisi tertentu, Pengelola Barang dapat melakukan Penilaian kembali atas nilai Barang Milik Negara/Daerah (BMN/D) yang telah ditetapkan dalam Laporan Keuangan Pemerintah Pusat/Daerah.

Keputusan untuk melakukan Revaluasi aset atas nilai Barang Milik Negara dilaksanakan berdasarkan 
ketentuan Pemerintah yang berlaku secara nasional. Sesuai dengan penjelasan Pasal 52 ayat (2) bahwa yang dimaksud dengan ketentuan Pemerintah yang berlaku secara nasional yaitu kebijakan yang ditetapkan oleh pemerintah untuk seluruh entitas pemerintah pusat. Berdasarkan ketentuan 2 PP tersebut, pada dasarnya penilaian kembali atas aset tetap tidak diperbolehkan kecuali ada ketentuan pemerintah yang berlaku secara nasional.

Menyadari bahwa sejak inventarisasi dan penilaian atas BMN yang dilakukan 2007-2010, telah terjadi kenaikan nilai BMN, terutama tanah yang cukup signifikan sehingga perlu penyesuaian nilai BMN sesuai dengan nilai wajarnya. Berdasarkan Surat Dewan Perwakilan Rakyat (DPR) RI Nomor PW/09793/DPR RI/2016 tanggal 9 Juni 2016 hal Hasil Keputusan Raker Komisi XI DPR RI dengan Menteri Keuangan pada tanggal 23 Mei 2016 yang salah satu isinya adalah meminta Menteri Keuangan untuk melakukan revaluasi aset terhadap BMN yang akan digunakan kembali (roll over) untuk penerbitan underlying asset SBSN.

Permintaan DPR ini juga menjadi salah satu hal yang melatarbelakangi pelaksanaan Penilaian Kembali BMN. Menindaklanjuti hal tersebut, pemerintah kemudian merencanakan pelaksanaan penilaian kembali atas Barang Milik Negara berupa berupa tanah, bangunan, Jaringan, jalan, danirigasi (berupa jalan dan jembatan serta bangunan air/JJBA) yang diperoleh sampai dengan 31 Desember 2015, dengan pertimbangan sebagai berikut:

1. Potensi Perubahan (kenaikan) nilai aset tetap berupa tanah, bangunan dan JJBA cukup signifikan.

2. Nilai wajarnya sangat besar dari keseluruhan aset tetap di LKPP.

3. Jumlah bidang tanah, unit bangunan, serta unit Jaringan, jalan, dan irigasi relatif lebih sedikit dibandingkan jumlah unit mesin dan peralatan serta aset lainnya yang sangat banyak dengan nilai per unit yang relatif kecil.

4. Saat ini, sebagian BMN berupa tanah, bangunan, serta Jaringan, jalan, dan irigasi menjadi underlying asset SBSN.

\subsection{Tujuan Revaluasi}

Tujuan dilakukan revaluasi aset BMN adalah untuk meningkatkan keakuratan nilai BMN yang disampaikan dalam laporan keuangan pemerintah pusat, menjadi underlying asset sebagai dasar diterbitkan Surat Berharga Syariah Negara (SBSN), membuat data base BMN yang selama ini masih belum baik menjadi lebih baik, serta menginventarisasi dan identifikasi BMN yang idle. Selain itu juga bertujuan menggambarkan dampak perubahan nilai aset karena Berubahnya nilai tukar dan kurs akibat inflasi atau deflasi, sehingga laporan keuangan dapat bersifat sebanding, bisa dimengerti, dapat diandalkan, and relevan. Selain itu adalah untuk meningkatkan penjualan dan mendapatkan pinjaman dari luar negeri (Nichols and Buerger, 2002).

\subsection{Rumusan Masalah}

Revaluasi aset BMN dengan jumlah aset yang sangat besar dan dilakukan dalam waktu sangat singkat, sejak bulan Agustus 2017 sampai dengan Agustus 2018, memberikan masalah bahwa tingkat keakuratan nilainya yang masih kurang, dan hal ini menyebabkan pencatatan neraca pemerintah pusat terkait aset tetap belum dapat diterima oleh Badan Pemeriksa Keuangan (BPK). Revalusi aset juga membutuhkan uang yang sangat besar, kerja keras untuk menyelesaikan revaluasi yang besar dari berbagai unsur. Sementara menurut Pernyataan Standar Akuntansi Pemerintahan (PSAP) 07 tentang Aset Tetap Paragraf 59, menyatakan bahwa "revaluasi aset tetap pada umumnya tidak diperbolehkan, alasannya bahwa Standar Akuntansi Pemerintahan menganut penilaian aset berdasarkan harga perolehan atau harga pertukaran.

Tetapi di satu sisi bahwa Revaluasi aset BMN adalah untuk membangun database nilai wajar tanah BMN yang bersifat real, akuntable dan up-to-date, karena sampai dengan saat ini pemerintah belum memiliki database dimaksud. Tidak adanya database tersebut menyebabkan pemerintah selalu lambat dalam menampilkan neraca aset tetap. Kondisi yang paling besar berpengaruh adalah terkait nilai tanah.

Jika kita bandingkan dengan negara tetangga Malaysia, sudah mempunyai basis data (database) nilai tanah dan bangunan yang dikelola dengan baik. Saat ini seluruh tanah di wilayah Malaysia telah memiliki nilai. (Rahah binti Ismail, JPPH Malaysia), sejak 1980 Malaysia sudah tahu nilai tanah dan bangunan secara nasional. Database nilai dikelola oleh lembaga bernama National Property Information Centre (NPIC).

\section{METODOLOGI PENELITIAN}

\subsection{Jenis dan Sumber Data}

Dalam melaksanakan penelitian penulis menggunakan metode kualitatif yang bersifat deskripsi naratif, dengan menganalisa dan menjelaskan permasalahan terkait pelaksanaan Revaluasi Aset Barang Milik Negara di Indonesia. Dengan memperhatikan kendala-kendala yang ada dalam Pelaksanaan kegiatan tersebut, dilakukan analisa 
Menggunakan hasil dari data primer dan data sekunder. Data primer, adalah data yang diperoleh secara langsung dari sumber data, yaitu orang yang dianggap mengerti dalam memberikan informasi yang benar dan sebenarnya di lapangan melalui wawancara. Sedangkan data sekunder, yaitu data pendukung yang diperoleh dari literatur-literatur dan dokumendokumen, penelitian serta laporan-laporan yang berhubungan dengan permasalahan apa yang diteliti. Penelitian ini bersifat deskriptif, yaitu menggambarkan dan menjelaskan secara jelas atas pertanyaan yang diajukan dalam penelitian ini. Kemudian dari hasil evaluasi dan analisa dapat diambil kesimpulan dan rekomendasi dalam melakukan pelaksanaan dan perbaikan revaluasi aset BMN di Indonesia.

\subsection{Teknik Analisis Data}

Berdasarkan data-data yang diperoleh dari akan digunakan sebagai dasar dalam memberikan gambaran kondisi serta gejala-gejala pada permasalahan yang akan diteliti. Analisa data dilakukan dengan menggunakan metode kualitatif. Dalam memenuhi tujuan dan fungsi penelitian, analisa data akan dilakukan untuk menyajikan dan menyampaikan berbagai alternatif solusi melalui evaluasi kebijakan dan pembahasan untuk diambil kesimpulan dan saran.

\section{PEMBAHASAN MASALAH}

Pada kerangka ini akan disampaikan beberapa literatur dan dan aturan mengenai revaluasi aset tetap. Metode revaluasi aset timbul sebagai metode penilaian kembali aset tetap dan aset tidak berwujud, tetapi dalam penelitian ini hanya aset tetap saja yang dilakukan.

Perlu diketahui bahwa revaluasi aset tetap akan mempunyai impact peningkatan nilai tercatat atau penurunan nilai tercatat semula, yang berlaku juga pada pemerintah.

\subsection{Revaluasi dan Penurunan Nilai Aset}

Revaluasi aset akan berdampak dengan meningkatnya nilai Aset Tetap atau menurunnya nilai Aset Tetap. Sementara dalam Akuntansi penurunan nilai (impairment of assets) terdapat pada Standar Akuntasi Keuangan (SAK), tidak terdapat pada Standar Akuntansi Pememrintah (SAP).

\subsection{Menurut Standar Akuntansi Pemerintahan}

Dalam Peraturan Pememrintah Nomor 71 SAP Akrual Paripurna tentang SAP Akuntansi Aset Tetap menyatakan bahwa revaluasi aset tetap pada umumnya tidak diperbolehkan karena SAP menganut penilaian aset berdasarkan harga perolehan atau harga pertukaran. Penyimpangan dari ketentuan ini mungkin dilakukan berdasarkan ketentuan pemerintah yang berlaku secara nasional. Catatan Atas Laporan Keuangan harus menjelaskan penyimpangan dari konsep biaya perolehan dalam penyajian aset tetap di neraca, CALK menjelaskan pengaruh penyimpangan tersebut terhadap kondisi keuangan pemerintahan.

\subsection{Menurut Standar Akuntansi Keuangan atau IFRS}

Standar yang mengatur tentang menurunnya nilai aset (Impairment of Assets) sebagai pelengkap metode revaluasi dan metode biaya pada akuntansi aset tetap ada pada IFRS/SAK. Selain itu IFRS juga mengenalkan teknologi revaluasi lengkap terhadap seluruh aset dan seluruh Liabilitas atau kebalikan dari aset yang merupakan sesuatu yang harus dimiliki /hutang yang harus dilunasi. Laporan Keuangan hasil penilaian kembali menggambarkan nilai wajar aset secara keseluruhan, termasuk piutang dan persediaan. Sisi hutang/liabilitas hasil revaluasi dapat bernilai lebih besar dari saldo hutang sebelum revaluasi, apabila dinilai dengan pendekatan pendapatan nilai kini terdiskonto. Hal itu berakibat aset dapat naik atau turun, Hutang yang harus dilunasi dapat naik atau turun, dan mengubah jumlah ekuitas neto naik atau turun.

PSAK memperbolehkan setiap unit Laporan Keuangan memilih berakuntansi dengan revaluasi atau model biaya. Tidak dikatakan bahwa ketentuan pemerintah berlaku secara nasional untuk revaluasi aset tetap berlaku bagi model penilaian kembali/revaluasi atau model biaya. Contoh ketentuan pemerintah berlaku nasional adalah PMK 191 tahun 2015 yang mengatur bahwa revaluasi kembali dapat dilakukan setelah 5 tahun revaluasi sebelumnya, revaluasi berlaku hanya untuk aset tetap yang berada di Indonesia, revaluasi boleh dilakukan terhadap sebagian aset tetap yang sejenis dan perbedaan nilai buku dengan nilai hasil revaluasi di catat pada ekuitas Laporan Keuangan pada unit dalam judul pos Selisih Lebih Penilaian Kembali Aset Tetap.

Oleh PSAK dinyatakan apabila unit atau organisasi menggunakan model penilaian kembali, unit/organisasi itu boleh melakukan revaluasi sebagian demi kelompok aset tetap, tidak perlu revaluasi seluruh aset tetap. Dalam PSAK dinyatakan apabila suatu aset dilakukan penilaian kembali, maka seluruh aset tetap dalam kelas yang sama telah direvaluasi. Yang dimaksud kelas aset tetap adalah pengelompokan aset sejenis atau bersifat sama dengan penggunaan/kegunaan mirip pada unit/organisasi tersebut. Contoh kelas aset tetap adalah tanah, tanah dan bangunan, mesin dan peralatan pabrik, alat transportasi darat, laut dan udara, perabotan dan peralatan kantor. Kenaikan nilai akibat 
revaluasi dicatat pada ekuitas, penurunan dicatat pada laba rugi.

Tidak diatur dalam SAP tentang akuntansi revaluasi aset tetap dan SAK mengizinkan revaluasi parsial, yaitu berdasar kelas aset tetap. Sehingga disimpulkan oleh Pemerintah bahwa, Peraturan Pemerintah atau PMK untuk revaluasi aset tetap Pemerintah dapat menggunakan analogi SAK tersebut.

\subsection{Menurut Pemerintah}

Setelah diterbitkannya Perpres Nomor 75 Tahun 2017 Pemerintah melaksanakan revaluasi aset tetap menggunakan nilai wajar, yaitu dengan melakukan penilaian terhadap aset tersebut ke lokasi dan tidak boleh terdapat nilai wajar aset yang usang yang telah direvaluasi. Nilai Wajar biasanya ditentukan oleh penilai atau appraisers, menggunakan bukti analisa data pasar (market research). Sedangkan untuk aset tetap bukan yang baru, menggunakan pendekatan biaya dengan metode depreciated replacement cost /DRC (biaya pengganti yang telah disusutkan) atau depreciated reproduction cost. Ada tiga metode pengukuran nilai wajar terkait revaluasi aset tetap BMN, meliputi :

1. Observable market transactions for same kind of assets (survei Transaksi pasar untuk jenis aset yang sama);

2. Observable market transactions for similar assets (survei transaksi pasar untuk aset yang sejenis/mempunyai kemiripan);

3. The use of valuation model (Menggunakan model penilaian).

Negara Kesatuan Republik Indonesia (NKRI) adalah sebesar Eropa, sementara revaluasi untuk aset tetap dengan persebaran sekitar 7.504 pulau membutuhkan energi yang besar dantidak cukup dilakukan hanya dalam satu tahun.

Berdasarkan hasil penilaian kembali aset pemerintah 2017 dapat digabungkan dengan hasil penilaian kembali aset tahun 2018 dengan memberikan faktor penyesuaian lintas tahun, contoh angka inflasi pada tahun 2017 sebagai proksi annual increase on general price index. Yaitu dengan cara hasil revaluasi tahun 2017 dikalikan (100\% + \% inflasi aktual 2017) menjadi setara hasil revaluasi tahun 2018 itu sendiri, sebelum digabungkan dan dilaporkan pada LKPP tahun buku berakhir 31 Desember 2018.

Metode Pengukuran ini diungkapkan pada Catatan Atas Laporan Keuangan (CALK). Sesuai Peraturan Presiden Nomor : 75/2017 tentang Penilaian kembali Pasal 9, dan PMK 118/2017 PASAL 13, Revaluasi aset BMN menggunakan tiga pendekatan penilaian yaitu : Pendekatan Biaya, Pendekatan Data Pasar, dan Pendekatan Pendapatan.

Revaluasi aset BMN dilakukan secara nasional hanya bagi Pemerintah Pusat, walaupun Perpres 75 disebutkan untuk BMN dan BMD, namun karena ketiadaan Permendagri tentang Pedoman Revaluasi BMD Perpres 75 dan ketidaksiapan pemerintah daerah dalam menyikapi Perpres 75/2017 tidak mengakibatkan Perpres tersebut menjadi batal.

Peraturan presiden dan Peraturan Menteri Keuangan taat pada penyelesaian revaluasi aset tetap BMN secara tuntas, adalah sesuai Standar AP. Apabila semua aset tetap harus selesai direvaluasi dalam satu tahun buku (tanpa ada item/butir aset tetap yang tertinggal), dan apabila hal tersebut tidak mungkin dilaksanakan dalam satu tahun buku, kesimpulannya adalah bahwa Pemerintah Pusat di masa yang akan datang tidak pernah dapat melakukan pemutakhiran neraca berbasis nilai historis sampai kapanpun, atau melaksanakan penilaian kembali aset tetap dengan kualitas yang diragukan dan biaya amat besar karena terburu-buru dan hasilnya tidak bisa dipertanggungjawabkan.

Dari sisi material, Peraturan Presiden, Peraturan Menteri Keuangan tentang revaluasi aset tetap telah memenuhi syarat Standar Akuntansi Pemerintah. Pelaksanaan revaluasi aset tetap yang terpaksa lintas tahun buku Pemerintah Pusat alias melebihi target waktu yang ditentukan, sepanjang dilakukan secara Good Corporate Governance, efektif, efisien, ekonomis dan dapat dipertanggungjawabkan (auditable) BPK.

Percampuran harga perolehan dan nilai hasil penilaian kembali pada suatu kelas aset tetap dalam neraca pemerintah menyebabkan derajat pengungkapan lengkap dan menyeluruh (full disclosure) menurun, akuntabilitas juga menurun, begitu juga transparansinya menurun. Biaya dibandingkan manfaat revaluasi tidak dapat di evaluasi. Kesulitan akan muncul pada pengaturan umur ekonomis aset tetap revaluasi yang baru, kesulitan menentukan APBN pemeliharaan dan nilai residu, sulit melaksanakan jurnal revaluasi pada item yang direvaluasi.

Jika aset tetap tidak mungkin selesai direvaluasi pada satu tahun buku, karena begitu kompleksnya permasalahan mengenai aset tetap, data, jumlah, maka pemerintah harus menetapkan sendiri metode revaluasi sesuai hak yang diberikan oleh SAP. Peraturan Presiden dan Peraturan Menteri Keuangan tentang Revaluasi dewasa ini merupakan kebijakan.

Ketika revaluasi aset itu dilakukan oleh pemerintah, diketahui bahwa singkatnya waktu penyelesaian revaluasi BMN, menimbulkan banyak temuan yang dilakukan oleh BPK atas hasil audit 
revaluasi aset tahun 2017-2018, yaitu bahwa di Indonesia itu tidak mempunyai data base transaksi jual beli tanah yang sudah terjadi, seperti dinegara-negara lain. Ini menjadi kesulitan penilai dalam mencari data pembanding dengan metode perbandingan data pasar.

Kecenderungan yang terjadi bahwa, penilai mendapatkan pembanding yang bukan sejenis dan sebanding, contoh : pada saat melakukan penilaian tanah, berarti menggunakan methode perbandingan data pasar, yang seharusnya pembanding objek adalah berupa tanah kosong, karena tidak adanya data base transaksi jual beli tanah di Indonesia dalam suatu kawasan, yang sering dijumpai adalah mendapatkan transaksi jual beli tanah berikut dengan segala sesuatu diatasnya, sehingga penilai harus menggunakan metode ekstraksi dalam memisahkan antara harga tanah dan harga bangunan artinya memerlukan waktu yang lebih lama dan kurang efektif. Yang terjadi saat ini hanya menggunakan 2 pembanding atau 3 pembanding, padahal semakin banyak pembanding, tentu akan lebih baik dalam menentukan nilai tanah.

Nilai tanah adalah sehubungan dengan adanya pemanfaatan dan penggunaan tanah sebagai gambaran ilustrasi, dimana harga tanah menjadi refleksi dari nilai tanah dan sering digunakan sebagai acuan bagi nilai tanah. Sementara Harga tanah bisa dikatakan sebagai penilaian atas tanah yang diukur berdasarkan harga nominal dalam satuan uang untuk satuan luas tertentu pada pasaran lahan tertentu. Harga sebidang tanah ditentukan oleh jenis kegiatan yang ditempatkan di atasnya dan terwujud dalam bentuk penggunaan tanah. Harga tanah dalam keadaan sebenarnya dapat digolongkan menjadi dua yaitu : harga tanah pemerintah (Goverment Land Price) dan harga tanah pasar (Market Land Price), dan masingmasing mempunyai karakteristik harga.

Dalam kerangka ini sebenarnya pemerintah dapat menggunakan Zona Nilai Tanah (ZNT) sebagai alternative dalam menentukan nilai tanah dan mencari pembanding tanah. Zona Nilai. Tanah .adalah merupakan poligon yang menggambarkan nilai tanah yang relative sama dari sekumpulan bidang tanah didalamnya, yang batasanya bisa bersifat imajiner ataupun nyata sesuai dengan penggunaan tanah, atau bisa juga definisi dari sisi perpajakan adalah zona geografis yang terdiri atas sekelompok Objek Pajak (OP) yang mempunyai satu Nilai Indikasi Rata-rata (NIR) yang dibatasi oleh batas penguasaan/pemilikan objek pajak dalam satu satuan wilayah administrasi pemerintahan desa/kelurahan tanpa terikat pada batas blok. Sedangkan Nilai Indikasi Rata-rata (NIR) adalah nilai pasar wajar rata-rata yang dapat mewakili nilai tanah dalam suatu Zona Nilai Tanah (ZNT). Penilai harus melakukan penilaian tanah masal dulu untuk menentukan apabila di Indonesia saat ini sudah mempunyai data base seperti di Malaysia, semua transaksi jual beli tanah, penawaran tanah, sewa tanah sudah ada real time, sehingga ketika dibutuhkan kapan saja dipastikan selalu ada. Intinya sebelum dilakukan revaluasi aset tetap harus dibentuk dulu basis datanya, agar penilaian lebih efisien, efektif dan hasilnya dapat dipertanggungjawabkan.

Meskipun Kementerian Keuangan telah melakukan upaya-upaya untuk memitigasi risiko-risiko tersebut, namun hasil pengujian sementara menunjukkan bahwa upaya tersebut belum sepenuhnya efektif. Hasil pemeriksaannya selesai pada akhir tahun 2018. Pemeriksaan ini akan menghasilkan satu Laporan Hasil Pemeriksaan secara nasional yang dapat memberikan simpulan berupa: (1) menerima; (2) menerima sebagian; atau (3) tidak menerima atas hasil penilaian kembali BMN Tahun 2017-2018. BPK berharap pemeriksaan ini dapat bermanfaat dalam mendorong pemerintah untuk mewujudkan hasil yang terbaik dalam pengelolaan aset negara dan sebagai bentuk tanggung jawab keuangan negara, khususnya terkait pengelolaan BMN. Hal ini sesuai dengan Visi BPK yaitu "Menjadi Pendorong Pengelolaan Keuangan Negara untuk mencapai Tujuan Negara melalui Pemeriksaan yang Berkualitas dan Bermanfaat". Pemeriksaan revaluasi aset sangat penting bagi negara. Perkembangan struktur neraca pemerintah pusat tahun 2010-2017, terdapat pola kenaikan baik dari sisi aset maupun kewajiban. Namun demikian, tidak terdapat kenaikan signifikan atas aset lancar, aset tetap, dan piutang negara jangka panjang dari tahun 2012-2017.

\section{KESIMPULAN DAN SARAN}

\subsection{Kesimpulan}

Berbagai ketentuan aturan dan kebijakan tentang revaluasi aset tetap BMN adalah merupakan salah satu upaya pemerintah untuk memperbaiki neraca pada Laporan Keuangan Pemerintah Pusat, dan ketika pemerintah memutuskan untuk melakukan revaluasi aset tetap BMN tentu mempunyai konsekuensi berat untuk menyelesaikannya dengan efektif, efisien dan akuntable. Peraturan Pemerintah dan Peraturan Menteri Keuangan tentang revaluasi aset BMN adalah merupakan kebijakan, karena pelaksanaan penilaian kembali atau revaluasi aset BMN pada umumnya tidak diperbolehkan karena Standar Akuntansi Pemerintah (SAP) menganut penilaian aset berdasarkan harga perolehan atau harga pertukaran. Hal ini dikatakan sebagai penyimpangan dari ketentuan PSAP 07. 
Peraturan pemerintah tentang Revaluasi Aset Tetap dapat mengatur metode penilaian yang lain, selain harga perolehan atau harga pertukaran. Peraturan Presiden Nomor 75/2017, diturunkan menjadi Pasal 19 ayat (10) PMK 118/2017 mengatur bahwa hasil revaluasi dalam suatu semester harus dinyatakan dalam perubahan nilai BMN dan Laporan Keuangan semester tersebut. Mematuhi Peraturan Menteri Keuangan tersebut, Laporan Keuangan tahun 2017 mencakup hasil revaluasi Aset Tetap tahun 2017.

Disimpulkan bahwa surat KSAP tersebut mendukung pelaporan hasil penilaian kembali atau revaluasi Aset Tetap 2017 ke dalam Laporan Keuangan Pemerintah Pusat (LKPP) tahun 2018.

Melalui Revaluasi aset, akan menjadi semangat memperbaiki dan memelihara aset menjadi lebih baik, alasannya adalah ternyata nilainya sangat signifikan besar. Manajemen aset menjadi semakin serius, berperang terhadap kapasitas aset yang menganggur (idle capacity war) menjadi makin relevan dalam pemerintahan, mengingat beban obsolence/penyusutan aset paska penilaian kembali makin besar.

Revaluasi aset BMN memang perlu dilakukan, dan setelah Peraturan Presiden Nomor 75 tahun 2017 dikeluarkan pemerintah langsung melaksanakan dalam 2 tahun, untuk menyelesaikan kegiatan revaluasi BMN agar dapat menyajikan nilai wajar aset tetap pada Laporan Keuangan Pemerintah Pusat, dan penilaian kembali aset BMN tahun 2017 adalah merupakan upaya untuk meningkatkan kualitas nilai wajar yang telah tercatat pada necara keuangan mengingat kegiatan Inventarisasi dan Penilaian aset BMN dilakukan 10 tahun sebelumnya dan dengan perkembangan ekonomi negara saat ini tentu nilai aset BMN mengalami perubahan Yang signifikan dibandingkan dengan nilai wajar aset 10 tahun yang lalu.

Tentu ada keuntungan dan perlunya pertimbangan melakukan revaluasi aset ini, yang antara lain keuntungannya adalah berdampak efektif dan efisien bagi APBN, laporan keuangan akan menunjukkan posisi kekayaan yang wajar sehingga pengguna laporan keuangan dapat memperoleh informasi yang lebih akurat dan tepat dan meningkatkan kepercayaan masyarakat kepada pemerintah, menciptakan performance of balance sheet yang lebih baik, sebagai akibat meningkatnya nilai aset, dan sebagianya.

Pelaksanaan revaluasi aset BMN ini tentu ada dampak negatif, yaitu laporan operasional yang menyajikan surplus pada era sebelum revaluasi, jangan sampai justru akan menyajikan defisit setelah dilakukan penilaian kembali terhadap aset BMN, akibat peningkatan penyusutan aset tetap yang begitu besar, biaya revaluasi dalam APBN harus dipertimbangkan agar tidak dilakukan dengan pemborosan dan terkesan menghambur-hamburkan anggaran, dan manfaat revaluasi harus lebih besar dari biaya revaluasi. Sekalipun kebijakan revaluasi dalam bentuk Peraturan Presiden bagi seluruh Kementerian dan Lembaga kepemerintahan NKRI, mencakupi Pemerintah Daerah, bukan hanya Pemerintah Pusat NKRI. Tetapi sampai dengan saat ini Pemerintah Daerah belum mempunyai aturan pelaksanaan revaluasi aset BMD, walaupun demikian Perpres tidak dibatalkan.

Revaluasi aset tetap hanya bermanfaat sementara dan tidak berlaku selamanya, untuk beberapa tahun saja, kemudian laporan keuangan/neraca revaluasi terkena imbas inflasi tahunan dan perubahan nilai tukar. Sebuah analisa bahwa setelah penilaian kembali aset tahun 2017 dan 2018, maka laporan keuangan asset tetap pemerintah akhir tahun 2019, akhir tahun 2020 dan seterusnya tidak akan mampu menggambarkan kenaikan harga umum suatu properti, karena tingkat inflasi sekitar $4 \%$ s.d. $5 \%$ pertahun ditambah penurunan kurs Rupiah.

Apabila inflasi tahunan $4 \%$ s.d. $5 \%$ menggambarkan kenaikan harga harga pada umumnya, penilaian kembali aset setiap 5 tahunan atau proyeksi kenaikan properti sekitar $25 \%$ dalam neraca mungkin cukup besar dan signifikan untuk informasi para pemegang surat utang negara. Berbagai properti pemerintah sepanjang tol laut dan tol darat seluruh Indonesia akan berpotensi mengalami kenaikan harga pasar sampai $1.000 \%$.

Revaluasi aset BMN dilakukan secara jujur terpercaya dengan sistem, prosedur dan kertas kerja yang berkualitas tinggi.

\subsection{Saran}

Revaluasi aset Barang Milik Negara (BMN) akan meningkatkan keakuratan nilai BMN yang Disampaikan dalam laporan keuangan pemerintah pusat. Hasil dari revaluasi aset BMN dapat menjadi dasar underlying asset untuk penerbitan Surat Berharga Syariah Negara (SBSN). Paling penting adalah menciptakan data base Baramg Milik Negara yang lebih baik, serta mengidentifikasi Barang Milik Negara idle, sekalipun biaya untuk pelaksanaan revaluasi BMN menggunakan APBN begitu besar.

\section{KETERBATASAN}

Studi ini tidak terlepas dari adanya keterbatasan penelitian, keterbatasannya adalah hanya menggunakan studi literatur yang perlu dilakukan lagi studi lanjutan dan keterbatasan data yang diperoleh 
dalam penelitian ini, yang disebabkan karena prosedural yang harus ditempuh, sehingga tidak dicakup dalam jurnal penelitian ini (data terkait hasil revaluasi BMN tahun 2017 dan 2018).

\section{DAFTAR PUSTAKA}

Agus. 2011. Penilaian Kembali (Revaluasi) Aset Tetap. Online: http://agus3p.blogspot.com. (diunduh tanggal 30 Mei 2013).

Agus Widarjono.,2009. Ekonometrika Pengantar dan Aplikasinya. Edisi Ketiga. Yogyakarta: EkonomiAndison,. 2015. “ Fixed Asset Revaluation: Market Reactions. " Medan: Prosiding Simposium Nasional Akuntansike XVIII.Pp 1-16

Anonim. 2012. Revaluasi Aset Tetap (Penilaian Kembali Aset Tetap). Online: http://kjpp-akr.co.id. (diunduh tanggal 30 Mei 2013).

Martani, Dwi. 2011. Revaluasi Aset Tetap (Majalah BUMN Track, No. 52 Tahun V, November 2011) ISSN 2088-8317.

Maria, Evi. 2009. Penerapan Psak 16 (Revisi 2007) Dan PMK No. 79 Tahun 2008. Tentang Aset Tetap Pada Perusahaan Di Indonesia. Jurnal Komputerisasi Akuntansi: 79 - 81.

Nichols, L.M. and K.H. Buerger (2002), An Investigation of the Effect of Valuation Alternatives for Fixed Asset on The Decision of Statement Users in the United States and Germany, Journal of International Accounting Auditing \& Taxation, 11, 155 - 163.

Barry J.Epstein \& Eva K.Jermakowics, Interpretation and Application of IFRS 2008, hal. 261.

Tim Smith, E-economic Investopedia. 2019. Asset Valuation

Rahah, binti Ismail. Direktur Jenderal Jawatan Penilaian dan Perkhidmatan Harta (JPPH) Kementerian Keuangan Malaysia. Data adalah “Darah” Penilai.2016. djkn.kemenkeu.go.id.

Sugiyono, 2009. Metode Penelitian Kualitatif dan R\&D. Bandung: Alfabet
Suparno. "Revaluasi Aset” Artikel Universitas Mecu Buana 2012. Jakarta.

Sutrisno, 2003. Manajemen Keuangan (Teori, Konsep dan Aplikasi), Edisi Pertama. Yogyakarta : Ekonisia FE UII

Uniform Standards of Profesional Appraisal Practice edisi 2016-2017

Whittred, G and Chan, Y.K (1992). Asset revaluation and the mitigation of underinvestment. Abacus.28(1):58-73

Standar Penilaian Indonesia dan KEPI edisi VII /2018.

Pasal 5 ayat (2) Undang-Undang Dasar Negara Republik Indonesia Tahun 1945;

Undang-undang Republik Indonesia Nomor 1 Tahun 2004 tentang Perbendaharaan Negara.

Undang-Undang Nomor 17 Tahun 2003 tentang Keuangan Negara (Lembaran Negara Republik Indonesia Tahun 2003 Nomor 47, Tambahan Lembaran Negara Republik Indonesia Nomor 4286);

PP Nomor 71 Tahun 2010 tentang Standar Akuntansi Pemerintahan, pada Pernyataan Standar Akuntansi Pemerintahan (PSAP) 07 tentang Aset Tetap Paragraf 59

Peraturan Pemerintah Nomor 27 Tahun 2014 tentang Pengelolaan Barang Milik Negara/Daerah (Lembaran Negara Republik Indonesia Tahun 2014 Nomor 92, Tambahan Lembaran Negara Repubik Indonesia Nomor 5533);

Peraturan Presiden Nomor 75 Tahun 2017 tentang Penilaian Kembali Barang Milik Negara/Daerah (Lembaran Negara Republik Indonesia Tahun 2017 Nomor 175);

Peraturan Menteri Keuangan Nomor 118/PMK.06/2017 tentang Pedoman Pelaksanaan Penilaian Kembali Barang Milik Negara. Pasal 13.

Pernyataan Standar Akuntansi Keuangan (PSAK) 16. Revaluasi Aset Tetap Menurut PSAK 16. 